\title{
Vegetative parameters of apple cultivars in integrated and organic production systems
}

\author{
Dremák, P., Csihon, Á.\& Gonda, I. \\ University of Debrecen, Faculty of the Agricultural and Food Sciences and \\ Environmental Management, Institute of Horticulture \\ 138. Böszörményi str., Debrecen, H-4032, Hungary
}

\begin{abstract}
Summary: Success of apple production is highly influenced by the applied production system and the planted cultivar. In this paper growing characteristics of 39 apple cultivars were studied in integrated and organic production systems. These kind of parameters are less studied in the cultivar and training system examinations, although they have huge effect on the training and maintaining of canopy, on the pruning necessity, ultimately on the production costs. According to our results the thickness of the central axis of apple trees showed significant differences between the integrated and the organic systems. Axis of the trees with lower trunk thickness tapers more slightly in the integrated production system, than in the case of the trees with thicker trunk in the organic system. Thicker axis is not accompanied by thicker trunk, namely the thickness of the central leader starts to decrease stronger in the organic production system, compared to the integrated one.
\end{abstract}

Keywords: integrated production system, organic production system, apple cultivars, central axis thickness

\section{Introduction}

Two main environmentally friendly growing systems have been developed by now: integrated and organic. In the two systems different cultivars can be produced with diverse result. Based on Apáti's (2013) calculations in our country to achieve the profitability in the integrated system intensive training systems, modern cultivars and updated technology are needed, where the available yields are 40-60 tons/ha and the ratio of the first class fruits reaches $80-90 \%$. In the organic system $30-40 \%$ quality and quantity loss can be occurred due to the plant protection problems compared to the integrated technology (Gonda, 2005; Holb, 2004, 2007, 2008; Holb and Scherm, 2008). This level of yield loss already threatens the effectiveness of the long-term organic farming, and points out that planted cultivars play huge role in the success of the production (Dremák, 2015).

Tomcsányi (1973) claims that cultivar is a biological mean of production which determines basically the feature of the product. Production value of the cultivars is determined by the growing and the fruit bearing characteristics and the fruit quality in a complex way. Among the features of the cultivars growing characteristics are not detailed in most of the cultivar descriptions, they are handled just superficially. However comparing the vegetative parameters of the trees and canopies can ensure useful information for the producers during the tree training and maintaining (Csihon, 2015; Csihon et al. 2015).
Formed canopies must be easy to maintain. Application of Zahn's $(1986 ; 1990 ; 1994)$ principles serves it well. This method considers the thickness of the lower main branches and the trunk. Practically the optimal ratio can be applied also in all part of the central axis.

Using Zahn's principles during the training and maintaining of the canopy contributes notably to keep the optimal size of the intensive canopies with smaller spacing. It also makes easier the pruning and facilitate the forming of airy, harmonic, conical or cylindrical shaped canopy with adequate illumination (Gonda, 1995).

Gonda (1995) used the phrase 'balanced tree' for the tree which reflects a kind of physiological inner balance which is manifested also in external sight. Elemental criteria of the optimal canopy are the conical shape, that is the thickness and the length of the branches decrease from the bottom to the up. This state can ensure the best illumination of the trees under the domestic circumstances.

In our previous work (Dremák et al., 2015) effect of the integrated and organic production system on the thickness of the trunk was evaluated. According to the results the trunk thickness of the trees both in the initial and both in the later bearing period is higher in the integrated production compared to the organic one. In this paper thickness of the central axis is presented also in term of the production systems. 


\section{Materials and methods}

Observations were performed at the University of Debrecen, Pallag Experimental Station of Horticulture. Experimental orchard was planted in spring of 1997 on rootstock M.26 with 4.0 x 1.5 m spacing distances. Canopy of the trees is free spindle.

The cultivar collection consisted of 39 apple cultivars and was grouped to three classes as worldwide known-, resistantand historical Hungarian apple cultivars (Table 1).

Table 1. Classification of the apple cultivars (Debrecen - Pallag, 2010)

\begin{tabular}{|l|l|l|}
\hline \multicolumn{1}{|c|}{$\begin{array}{c}\text { Worldwide known } \\
\text { cultivars }\end{array}$} & Resistant cultivars & $\begin{array}{c}\text { Historical Hungarian } \\
\text { cultivars }\end{array}$ \\
\hline Gala Must & Pilot & Batul \\
\hline Golden Reinders & Reka & Mosolygós batul \\
\hline Csányi Jonathan & Relinda & Nyári fontos \\
\hline Ozark Gold & Renora & Téli aranyparmen \\
\hline Elstar & Reglindis & Téli banán \\
\hline Mutsu & Releika & Téli piros pogácsa \\
\hline Jonagold & Rewena & Darusóvári \\
\hline Golden Orange & Retina & Fertődi téli \\
\hline Ruby Gala & Remo & Francia renet \\
\hline Idared & Liberty & London pepin \\
\hline Granny Smith & Reanda & Gravensteini \\
\hline Pinova & Resi & Téli fehér kálvil \\
\hline Topaz & Faw 7262 & Húsvéti rozmaring \\
\hline
\end{tabular}

In this study from the growing characteristics thickness of the trunk and central axis is presented in term of the two production systems. Thickness of the trunk was measured at the half of the distance between the grafting union and the lower main branches. Thickness of the central axis was observed at the high of $100 \mathrm{~cm}$ and $150 \mathrm{~cm}$ from the ground. From the data a ratio was created, where the values in percentage form shows the thickness of the central axis compared to the trunk thickness.

This indicator has high importance, because represents well the harmonic structure of the trees and the balanced growing. If the thickness of the central leader decreases proportionally from the bottom to the up it can be assumed that the branches emerging from the axis will be proportionally thinner. The canopy is more like a cone or its projection of an equilateral triangle, the more favorable lighting conditions are there, thus the growing and the bearing processes are in balance. Yearly pruning of this kind of tree is more moderate, which means the least manual effort.

\section{Results and discussion}

Ratio of the central axis and trunk thickness in the integrated production system is presented in Figure 1.

Huge differences can be seen among the cultivars. Among the worldwide known, the historical and resistant there are no tendencies, as all three groups have members also with high and low values.

Thickness of the central axis at $100 \mathrm{~cm}$ high compared to the trunk is under than $50 \%$ in the case of the cvs 'Pilot' (41\%),'Fertődi téli' (45\%) and 'Rewena' (49\%). Majority of the cultivars (altogether 25 cultivar) reached the value between $50-60 \%$.

Cvs 'Francia renet' (60\%), 'Húsvéti rozmaring' (62\%), 'Gravensteini' (74\%) and 'Reglindis' (75\%) showed much stronger thickening at $100 \mathrm{~cm}$ high. It is interesting, that from these cultivar none of them belongs to the worldwide cultivars with high productivity. According to our opinion they are more or less closer to the less domesticated wild apple regarding its morphological structure. It should be mentioned also, that the yields of these historical cultivars can't even approach the accomplishment of the worldwide cultivars with more moderate central axis thickness.

Thickness of the central axis at $150 \mathrm{~cm}$ high is probably influenced by the diverse crop load of the different years. Cvs 'Pilot' (25\%) and 'Fertődi téli' (25\%) showed the lowest values. 12 cultivars can be grouped with similar thickness (30-40\%). From them cvs 'Rewena' (30\%) and 'Idared' (30\%) presented smaller, cvs 'Mutsu', 'Téli fehér kálvil', 'Renora', 'Gala' (37-37\%) and 'Reka' (38\%) displayed higher ratio.

Other 15 cultivars reached the value between $40-50 \%$. Among them the thickness of the axis of cvs 'Téli banán' (42\%) and 'London pepin' (42\%) is lower, cvs 'Batul' (48\%), 'Reanda' (48\%), and 'Húsvéti rozmaring' (49\%) is higher.

Cvs 'Retina' (50\%), 'Reglindis' (57\%) and 'Gravensteini' $(74 \%)$ reached extremely high, more than $50 \%$ ratio. In

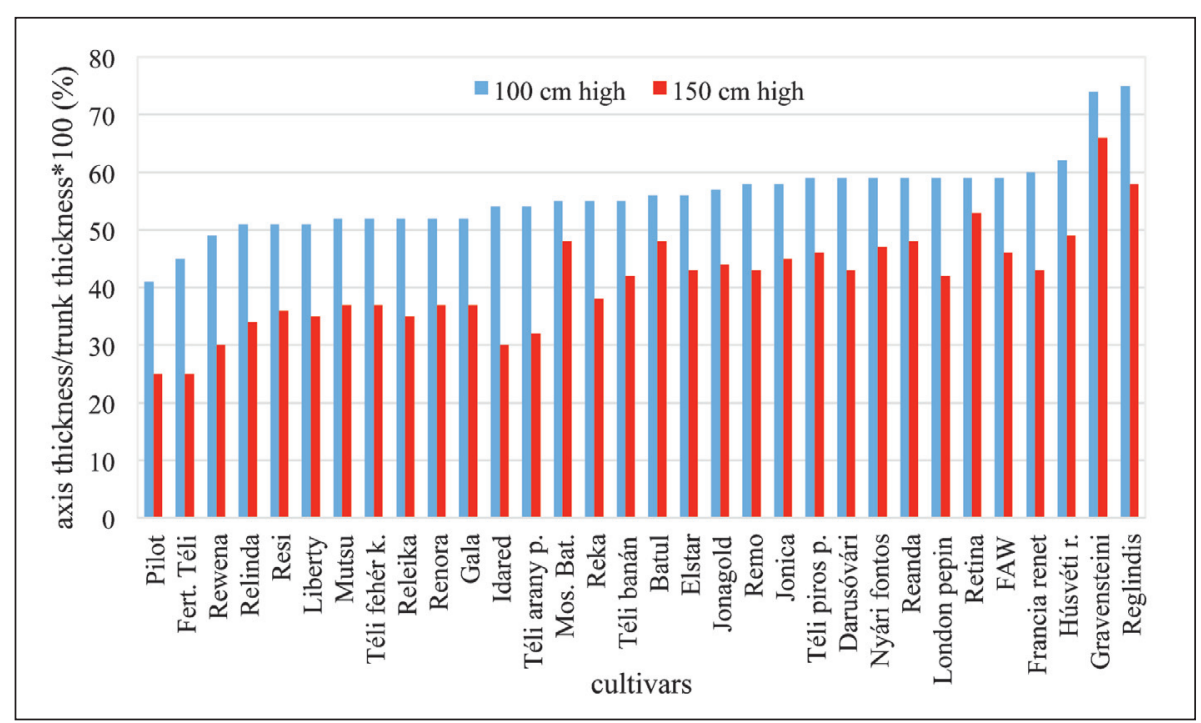

Figure 1. Ratio of the central axis and trunk thickness of 14 years old apple trees in integrated production system (Debrecen - Pallag, 2010). 
the case of these cultivars supposedly the effect of the wild parental cultivars can be monitored, as causing huge challenges in the technology due to the natural globular canopy structure.

According to the thickness of the trunk and the central axis it can be stated that cvs 'Pilot' (ratio of $41 \%$ and $25 \%$ in the two high region) and 'Fertödi téli' $(45 \%, 25 \%)$ are considered to be the most easily sustainable cultivars, as the thickening of the axis is favorable, it is the weakest compared to the other cultivars. At the same time it can be also a negative phenomenon. Namely the strong tapering of the upper third of the canopy can result the radical loss of the cropping surface thanks to the determined tree height. In the case of these cultivars interventions aiming to increase the tree height (e.g. cutting back the leader shoot) are mostly unsuccessful.

Hardly trainable and maintainable group of cultivars involves cvs 'Retina', 'Reglindis' and 'Gravensteini', where thickness of the central axis at $150 \mathrm{~cm}$ high reached the 50\% compared to the trunk.

Based on the above mentioned it can be seen, that only cultivars with moderate vigor and thickening can ensure successful production and high productivity in a long term.

It is essential to emphasize, that these differences were observed in integrated production technology, where plant protection and fertilization are optimal. Therefore it is interesting to evaluate the cultivars also in organic production, where there are more disturbing circumstances on the plant shape.

Effect of the organic production on the ratio of the central axis and trunk thickness is shown in Figure 2.

It can be seen, that between the highest and lowest values of the axis thickness at $100 \mathrm{~cm}$ high the difference is much smaller in the organic farming compared to the integrated one. The values are between $39 \%$ and $61 \%$. Cvs 'Pilot' (39\%) and 'Fertödi téli' (39\%) thickened at least. Most of the cultivars reached the ratio of $40-50 \%$. 11 other cultivar can be described with thicker axis (above 50\%). Values of cvs 'Darusóvári' (56\%) and 'Reglindis' (61\%) outstands from the other in the organic system, as they showed more moderate thickening in the integrated production.

Regarding the $150 \mathrm{~cm}$ height also cvs 'Pilot' (21\%) and 'Fertődi téli' (19\%) showed lower values, but the thinner axis was measured on cv 'Idared'. In the case of the latter cultivar thickness of the axis is only $16 \%$ compared to the trunk, namely central leader tends to taper strongly.

At $150 \mathrm{~cm}$ height only cv 'Gravensteini' displayed value above $50 \%$. This part of the central leader showed very strong thickening, as its reached $69 \%$ compared to the trunk. 0
It may seem contradictory, as at $100 \mathrm{~cm}$ high thickness was lower $(55 \%)$. Trying to reduce the extremely strong vigor and growing habit of this cultivar by fitotechnical interventions was failed, as the upper third of the central leader over thickened.

However in the case of the most cultivar thickness of the central leader decreases strongly from the bottom to the up, almost atrophy can be seen. Cvs 'Pilot' (ratio of 39\% and $21 \%$ in the two high region) and 'Fertödi téli' (39\% and 19\%) proved to be easily maintainable.

Figure 2. Ratio of the central axis and trunk thickness of 14 years old apple trees in organic production

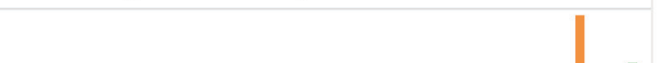

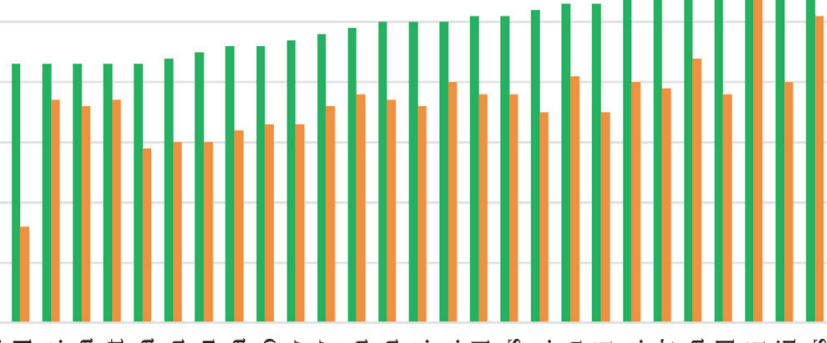

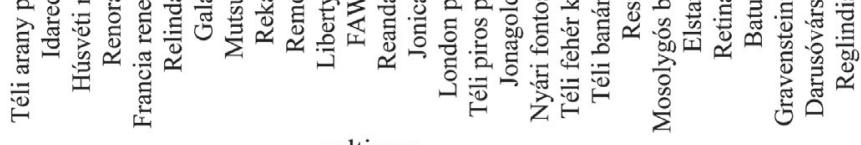

cultivars

\section{Conclusions}

Huge differences can be seen regarding the thickness of the central axis at $100 \mathrm{~cm}$ high compared to the trunk thickness between the integrated and organic production systems. All cultivars, except for three reached the $50 \%$ ratio in the integrated farming system. It means, that the axis of the trees with lower trunk thickness tapers more slightly in the integrated production system, than in the case of the trees with thicker trunk in the organic technology. Thicker axis is not accompanied by thicker trunk, namely the thickness of the central leader starts to decrease stronger in the organic production system, compared to the integrated one. The reason of this phenomenon can be that, the growing and shape of the trees was more favorable for the thickening of the trunk after a few years of the planting, than in the integrated system, where the more vigorous trees use more organic material for the growing and bearing. Moreover higher yields of the trees in the first some years can also cause lower trunk thickness in the integrated production. Later in the bearing period differences of the trees in growing and bearing in the integrated and organic production systems, ultimately the differences in their shape was so high, which was manifested also in the thickness of the trunk. 


\section{References}

Apáti, F. (2013): Az almatermelés üzemgazdasági megfontolásai. In.: Versenyképes almatermesztés. (Szerk.: Gonda I. - Apáti F.) Szaktudás Kiadó Ház. Budapest, 2013.

Csihon, Á. (2015): Új almafajták növekedési, terméshozási és gyümölcsminőségi tulajdonságainak vizsgálata. Doktori értekezés. DE MÉK. 173. pp.

Csihon, Á., Holb, I., Gonda, I. (2015): Growing characteristics of apple cultivars and canopies. International Journal of Horticultural Science 21(1-2): 7-10. p.

Dremák, P. (2015): Környezetkímélő alma termesztéstechnológiák összehasonlító vizsgálata. Doktori (PhD) Disszertáció. DE MÉK. Debrecen. 152. pp.

Dremák, P., Csihon, Á., Gonda, I. (2015): Growing characteristics of apple cultivars in environmentally friendly growing systems. International Journal of Horticultural Science 21(3-4): 7-10. p.

Gonda, I. (1995): Kiút a válságból. Intenzív almatermesztés. PRIMOM Kiadó, Nyíregyháza.163. p.

Gonda, I. (2005): Az ökológiai növényvédelem közvetett elemei. In. Holb, I. (szerk.): A gyümölcsösök és a szőlő ökológiai növényvédelme. Mezőgazda Kiadó, Budapest. 34-40. p.
Holb, I. J. (2004): The brown rot fungi of fruit crops (Monilinia spp.) III. Important features of their disease control. International Journal of Horticultural Science 10:(4) pp. 31-48.

Holb, I. J. (2007): Classification of apple cultivar reactions to scab in integrated and organic apple production systems. Can. J. Plant Pathol. 29(3): 251-260.

Holb, I. J. (2008): Monitoring conidial density of in the air in relation to brown rot development in integrated and organic apple orchards. European Journal of Plant Pathology 120:(4) pp. 397-408.

Holb, I. J., Scherm, H. (2008): Quantitative relationships between different injury factors and development of brown rot caused by Monilinia fructigena in integrated and organic apple orchards. Phytopathology 98: 79-86. p.

Tomcsányi, P. (1973): Piacos kertészet. Mezőgazdasági Kiadó, Budapest. 632. pp.

Zahn, F. G. (1986): Intensivierung von Steinobstanlagen durch starkenbezogene Schnittbehandlung. Erwerbs-Obstbau 28: 124-140.

Zahn, F. G. (1990): Die Spindel beim Steinobst-The Spindel for Stone Fruit trees. Erwerbsobstbau 32: 60-66.

Zahn, F. G. (1994): "Höhengerechter Pflanzabstand" durch “Starkbezogene Baumbehandlung” Erwerbs-Obstbau 36 (8):213-220. 